\title{
Learning Comics for Students in Citizenship Education
}

\section{Courses}

\author{
Heru Sofian*, Nurcholis Sunuyeko**, Titik Purwati***, Melisa Wahyu Fandyansari**** \\ * Economic Education, IKIP Budi Utomo, Malang, Indonesia \\ ** History and Sociology Education, IKIP Budi Utomo, Malang, Indonesia \\ *** Economic Education, IKIP Budi Utomo, Malang, Indonesia \\ **** Economic Education, IKIP Budi Utomo, Malang, Indonesia
}

DOI: 10.29322/IJSRP.10.11.2020.p10748

http://dx.doi.org/10.29322/IJSRP.10.11.2020.p10748

\begin{abstract}
Comics which were compiled as teaching material for Introductory Education courses were arranged because there was not any learning media has been used. Thus, the teaching and learning process feels monotonous and less interesting. The development of comics in the civic education course used research and development method from Borg and Gall. Testing was carried out on three experts, namely material, language and media experts, then a small-scale group test (20 students) and a large-scale group test was carried out on 60 students in Semester II. Data collection techniques used questionnaires, interviews, tests and documents. The results of the small-scale group test obtained a mean response of $86.3 \%$ and involved in very attractive criteria. The results on the large-scale group test obtained an average score of $88.7 \%$ which is also involved very interesting criteria. Based on the validation that has been carried out on experts, the mean score of the assessment is $86.9 \%$ which means it is very interesting and it is concluded that comic is suitable to be used in civic education course.
\end{abstract}

Index Terms- Comic, Civic Education

\section{INTRODUCTION}

$\mathrm{T}$ he development of science and technology is currently very rapid and has changed most aspects of people's lives. Almost all aspects of life have become practical since the rapid development of science and technology, and make people enjoy and prefer everything that is instantaneous. Likewise, it happens in the educational aspect. If technology is used positively, it has a very big and good impact on the development of education. The development of technology makes education more modern and raises many ideas that basically have the same purpose to facilitate understanding of education and improve human resources in the future.

Technology is very useful in the development of learning, because it can be a very powerful tool or medium for transforming learning material. In line with the very rapid development of information technology, it is starting to require teachers to be able to continuously update their knowledge and skills in creating creative and innovative learning media in every learning process. Therefore, in the world of education, it must adapt toward times period in order to be able to provide quality output as needed. Education is required to provide human resources who have high intellectuality, skills, and good character.

When we discuss education, it cannot be separated from learning activities. According to Yunita, (2017: 1) learning is a process of interaction or communication between learners, teachers, and teaching materials. (Suardi, 2018: 6) explains that learning is an effort that deliberately involves and uses professional knowledge possessed by an educator to achieve curriculum goals. Learning is a process of interaction between students and learning resources. Learning is an assistance provided by an educator to students so that there is a process of acquiring knowledge, mastery, proficiency, and the formation of attitudes and beliefs in students. So learning is a process in helping students learn well. The learning process can be experienced by human anywhere and anytime.

Every time you carry out the learning process, it is always desired to achieve predetermined goals. In order to achieve the desired learning objectives, good learning activities are needed. Good learning outcomes are obtained from several factors. One of these factors is through the learning media used by an educator in the classroom. (Sumiharsono and Hasanah, 2017: 10) suggest that in general, the media has used including: 


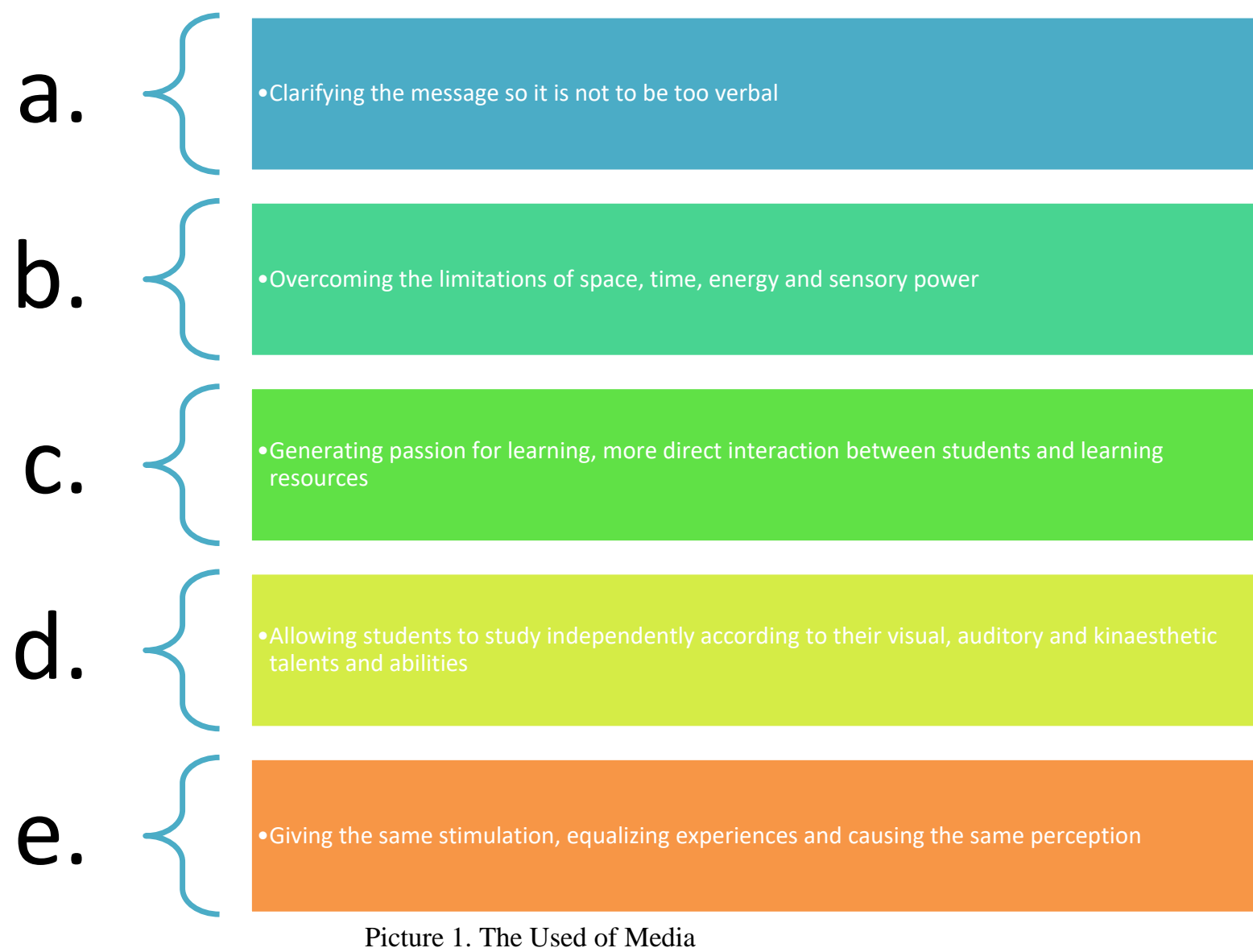

There are many things occur in the learning process. However, teachers only focus on delivering material to students without any media that can attract students' attention. It will make students have difficulty in achieving the learning objectives. Meanwhile, the use of relevant learning media in the classroom can help teachers deliver the material they want to convey. However, teachers should know the problems of students in the classroom before conveying the material. It aims to find out suitable learning media which will be used in the classroom. In using interesting teaching media, it will help students understanding the material being studied and make the learning process more enjoyable. The diversity of the media used in learning is really needed by teachers because interesting learning media will make students more enthusiastic in the learning process.

The teachers' task in delivering the material being taught is not only presented verbally, but also in a visual way. Learning sources which are usually used by teachers in the classroom are textbooks. However, relying solely on textbooks is not enough. Therefore, they need to develop teaching media that are innovative, effective and efficient. One of the media which can help teachers in learning activities is by using comic. (Darmawan in Hidayah, 2017: 37) explains that "a comic is a cartoon that describes a character who plays a story in a tight order, is connected to an image and is designed to provide entertainment to the readers". In addition, comic is a form of pictorial news, consisting of various situation stories that are continuous and sometimes humorous. From comic, it has purpose to be a source of learning and motivating students improving the results of learning. This time, the researchers chose to develop teaching media in the form of comics in the civic education course to be applied to students. The teaching media in the civic education course is presented in the form of comics expected to help students understanding the material easily. Therefore, the researchers want to conduct a research entitled "Learning Comics for Students in Civic Education Course". Based on the 'background' which has been explained, it can be concluded that the formulation of the problem in this study is: What is the level of effectiveness of comic as teaching media for students in civic education course? While the aim of researchers in conducting this research is to produce effective teaching media for students in civic education course.

\section{RESEARCH METHOD}

Research is a systematic activity in finding answers to an existing problem by collecting data for specific purposes. The development of comics in the civic education course used research and development method from Borg and Gall. In this research and development, the researchers simplified the development into seven steps into the final product and applied in educational institutions. Here, the seven development steps according to Borg and Gall (Slamet Riyanto and Aglis Andhita Hatmawan, 2020: 5-7): 


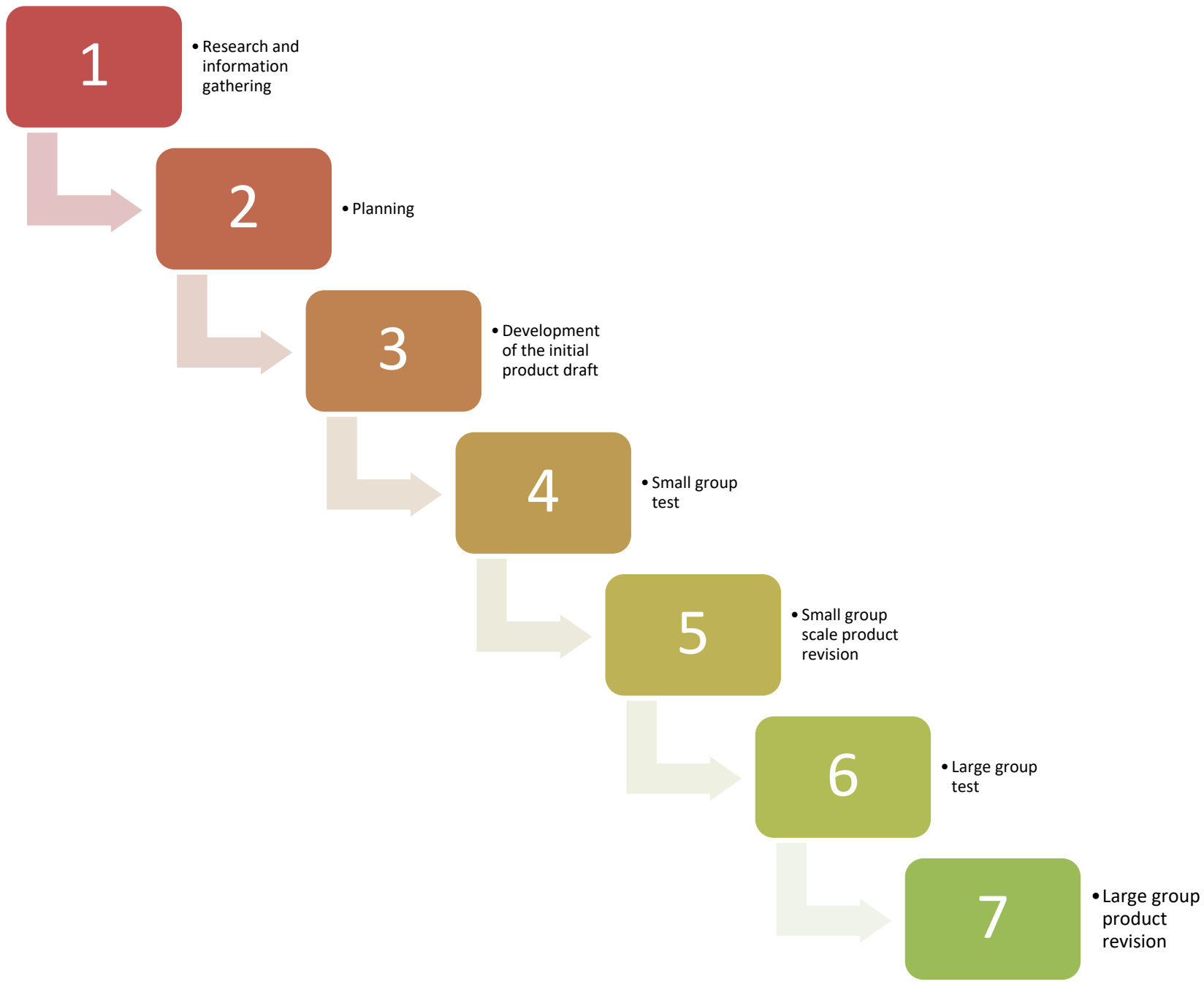

Gambar 2. Research Stage

The subject of the test was carried out on three experts, namely material, language and media experts, then small-scale ( 20 students) and large-scale group tests were carried out on 60 students of second semester-the academic year 2019. While the data collection techniques used questionnaires, interviews, tests and documents.

\section{FINDINGS AND DISCUSSION}

The researchers started the product creation in several stages, namely: 1) Plot design was carried out to determine the characters and storylines; 2) Creating and compiling scenarios using Microsoft word; 3) Comic design made and processed using Corel Draw. The format in this comic learning media consists of a cover page, character introduction, usage descriptions, learning materials formed in a comic, and question exercises. Below is an example of a comic image. 

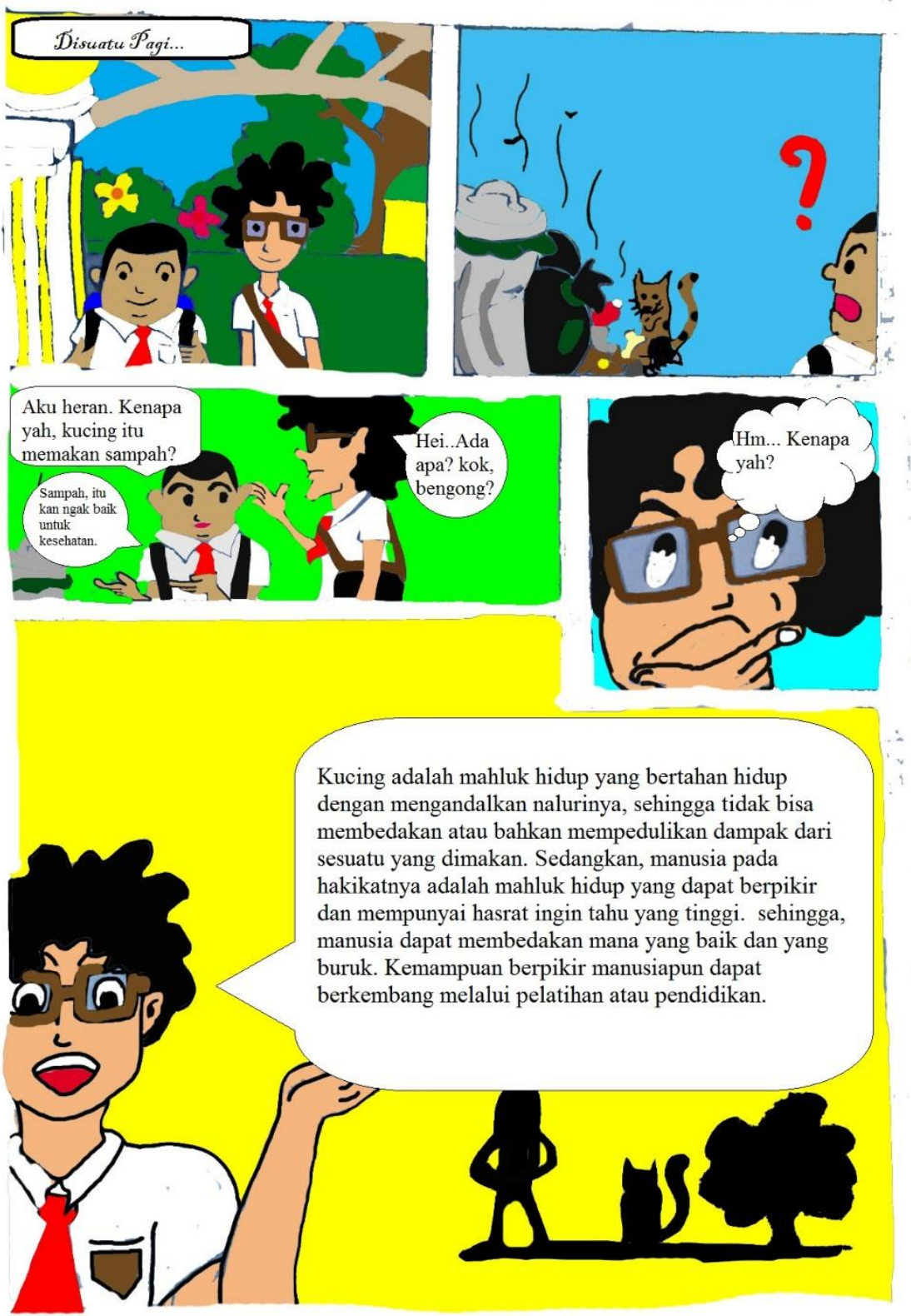

Figure 3. Comic 1 


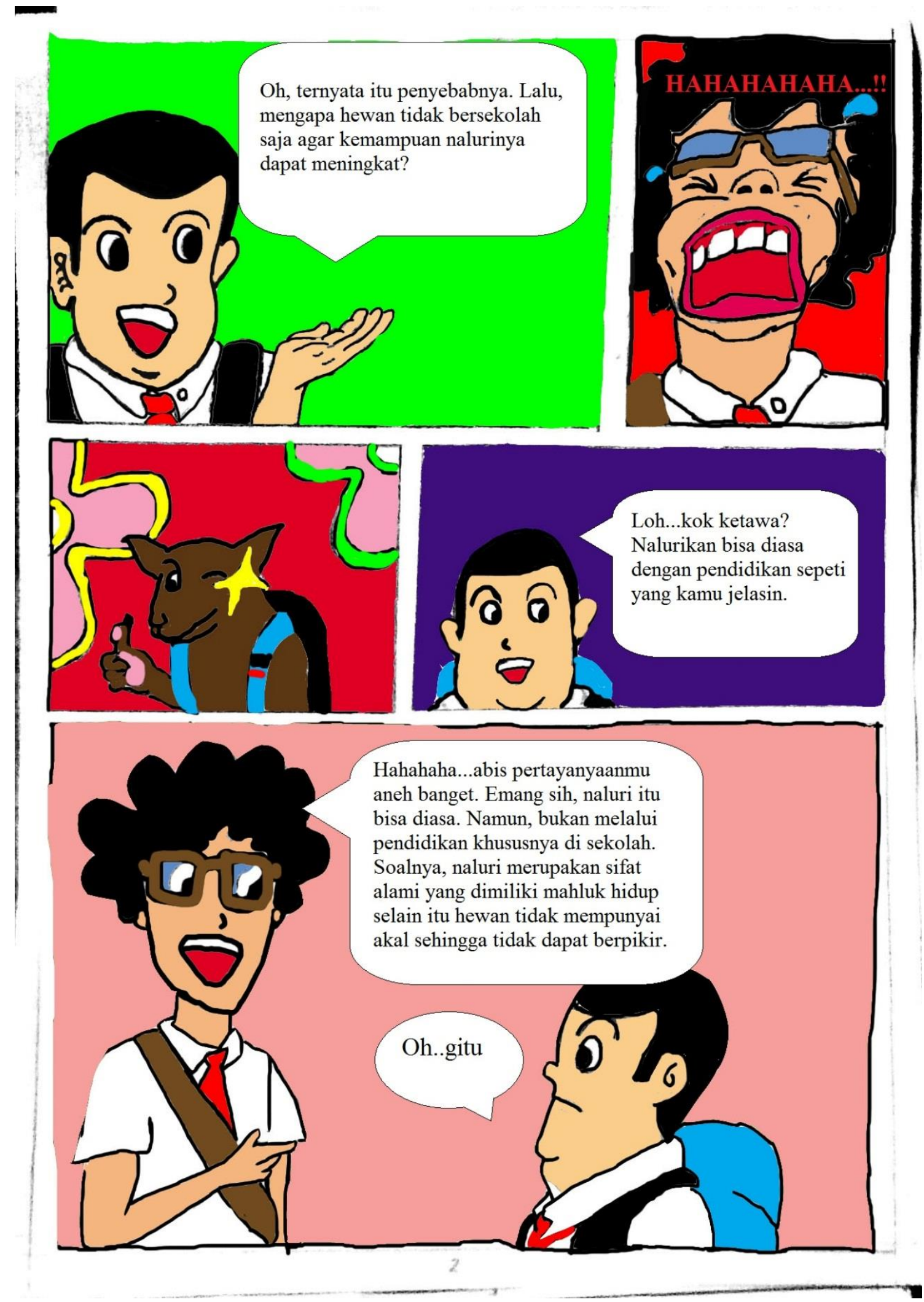

Figure 4. Comic 2 

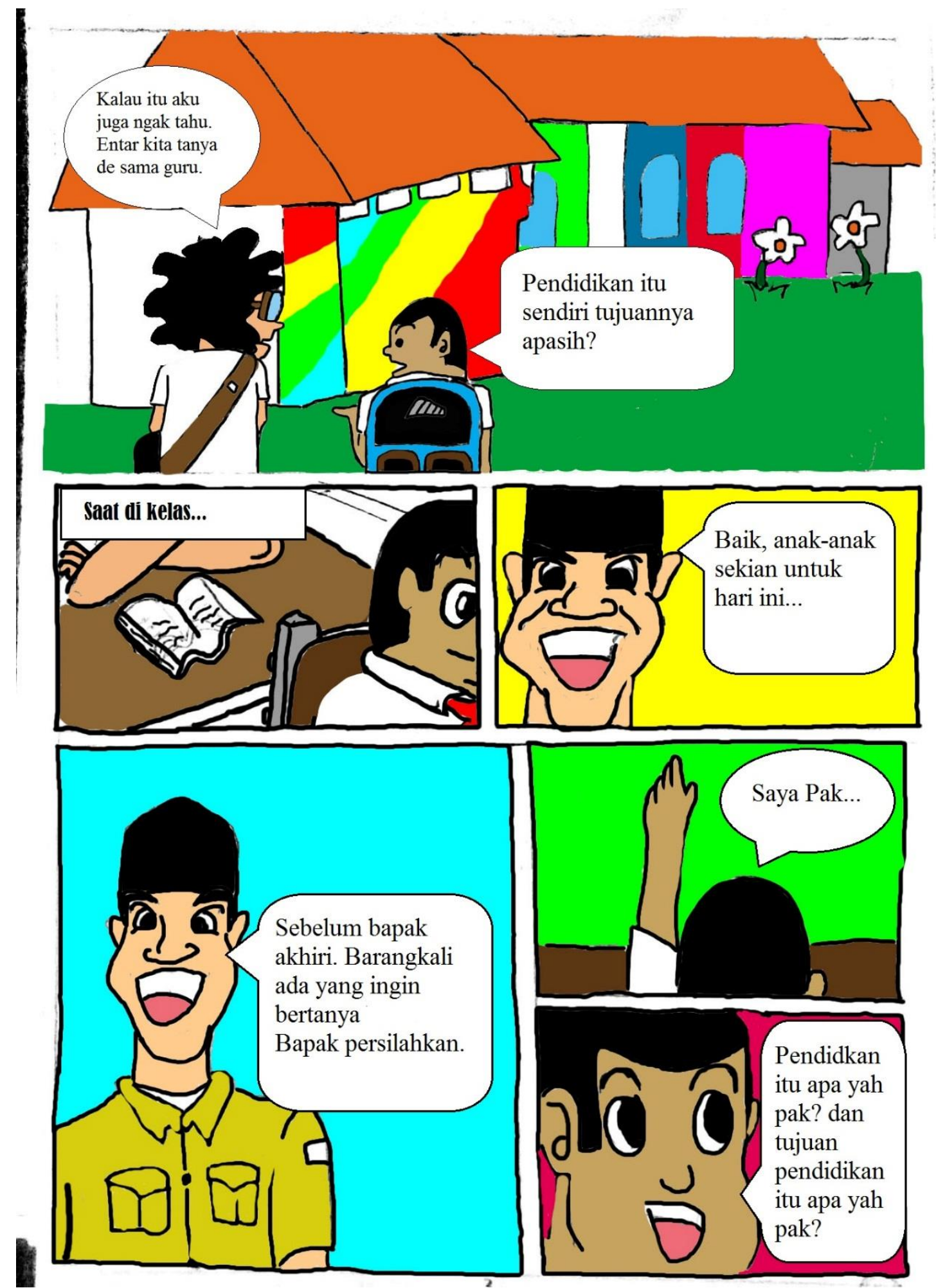

Figure 5. Comic 3

Before comic products are tested in the field, the products are first validated by material experts, language experts and media experts. Validation by experts is done, in order to make this comic can be developed and it is appropriate to be tested on students. In addition, experts' validation also can solve errors and deficiencies in the material. Thus, it does not experience many errors in accordance with what is needed by students. Based on the calculation of the assessment of each material expert validation in stage I, the observations made got a score of $78.6 \%$ and $75 \%$. These results have shown that comic is already in the feasible category to be used, but it still requires revision. After the second stage validation of the material expert, the score was obtained a mean of $100 \%$. For the validation 
of stage I language experts scores were $75 \%$ and $78.6 \%$. These results have shown that the comic is already in the feasible category to be used, but it still requires revision so that further validation is carried out in stage II which gets a score of $96 \%$ and $100 \%$. While in the stage I media expert validation obtained the score of comic was $78 \%$. These results have shown that the comic is already in the feasible category to be used but it still requires revision so that it is validated at stage II which gets a score of $100 \%$. If matched with the eligibility criteria, then all scores of achievement obtained are included in the valid criteria.

1. The Result of Comic Attraction Level Test.

The level of attractiveness of the comic got a very good response from students. It was shown from the results of the response of questionnaire given to students and it showed that comic is very interesting. The results obtained from trials on students in small groups got a mean score of $87 \%$. While trials in large groups got a mean score of $88 \%$. As for the statement given by one of the students regarding the existence of comic as teaching media, namely: "The existence of comic in the civic education course makes learning more enjoyable. It is because there is a story line and pictures that make the learning process less boring. The existence of this comic also makes the learning process easier to be understood".

2. Efficiency Test Results for Comic.

Learning by using comic can make students easier to understand the material. In addition, learning using comic can also be a good way to learn independently. Comic is more attractive for students because the contents are not only written, but also they are presented in the form of pictures.

3. Result of Comic Effectiveness Test.

In this small group test, the mean calculation of students' daily test results before using comic obtained a mean score of 76.8 . Meanwhile, the score obtained after using comic learning media is 84.7. It can be concluded that in the small group test the mean score obtained by students after using comic is greater than before using comic. In the large group test, the mean calculation of the results of students' daily tests before using comic obtained a mean score of 75.75. While the score obtained after using comic is 84.33 . It can be concluded that in the large group test the mean score obtained by students after using comic was greater than before using comic.

Comic can be said to be effective to be used in the learning process. It is shown by the results of trials with students on a small scale and trials on a large scale. This statement is supported by (Daryanto, in Fitra Yurisma Kanti, Bambang Suyadi and Wiwin Hartanto, 2018: 140) stating that teaching media can be said to be effective if it can increase the achievement of learning objectives. The level of achievement of these goals is in the form of increased knowledge, skills, and development of attitudes through learning process. So, it can be concluded that comic is very effective if it is used for learning civic education course.

\section{CONCLUSION}

Based on the research and development that has been done, it can be concluded that the Comic Teaching Media Development for civic education course refers to the development stage according to Borg and Gall which is grouped into seven stages. In research and development, an assessment of comic teaching media has been carried out by material experts, language experts and media experts. The score obtained for the comic instructional media in the civics education course falls into the very feasible category. Meanwhile, for students, it is conducted trials on a small scale and trials on a large scale. The scores obtained were also very different before and after using comic in teaching and learning process. It shows that comic can help students in learning and help students to understand easily the material they are learning. In addition, comic also helps teachers in teaching and learning process because it can be an alternative in the choice of teaching media and it makes teachers conveying material easily. Then, it can create a lively and fun learning atmosphere. The exercises contained in the comic can also be a benchmark for students so that teachers can evaluate the used of comic in teaching and learning process.

\section{REFERENCES}

[1] N. Irfana, "Pengembangan Komik Digital "Let's Learn About Virus" sebagai Media Pembelajaran Biologi Siswa Kelas X SMA (Unpublished work style)", unpublish

[2] N. Yunita, "Pengembangan Media Komik Digital Berbasis Contextual Teaching and Learning (CTL) Sebagai Media Pembelajaran Pada Materi Sistem Pernapasan Untuk Peserta Didik Kelas VIII SMP/MTs (Unpublished work style)", unpublish

[3] N. Irfana, R. S. Iswari, F. P. Martin, "Pengembangan Komik Digital "Let's Learn About Virus" Sebagai Media Pembelajaran Biologi Siswa Kelas X SMA", 6" ed. Vol 3, 2017 pp.

[4] Y. F. Hidayah, Siswandari, Sudiyanto, "Pengembangan Media Komik Digital Akuntansi Pada Materi Menyusun Laporan Rekonsiliasi Bank Untuk Siswa SMK", vol. 2, no.2, 2017

[5] K. M. N. Hidayah, "Pengembangan Media Komik Digital Menggunakan Pixton Disertai Quiz (Kahoot) Pada Konsep Sistem Gerak (Unpublished work style)", unpublish

[6] Musdalifah, "Pengembangan Media Komik Digital Pada Pembelajaran Matematika Materi Pengolahan Data di Kelas V MI Darussalam Curahmalang Jombang (Unpublished work style)", unpublish

[7] F. M. Rohmanurmeta, C. Dewi, Pengembangan Komik Digital Peletarian Lingkungan Berbasis Nilai Karakter Religi Untuk Pembelajaran Tematik Pada Siswa Sekolah Dasar, vol. 09, no. 022019 


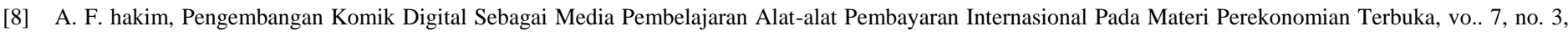
2018

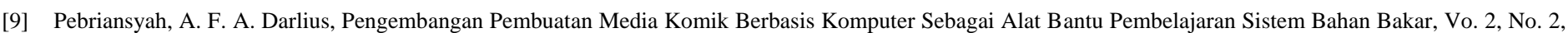
2015

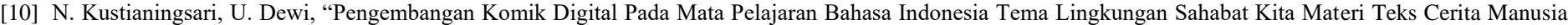
dan Lingkungan Untuk Siswa Kelas V SDN Putat Jaya III/379 Surabaya, (Unpublished work style)", unpublish

\section{AUTHORS}

First Author - Heru Sofian, S.H, M.Pd, lecturer, IKIP Budi Utomo, herusofian@ budiutomomalang.ac.id.

Second Author - Dr. Nurcholis Sunuyeko, M.Si, lecturer, IKIP Budi Utomo, nurcholissunuyeko@budiutomomalang.ac.id.

Third Author - Dr. Titik Purwati, M.M, lecturer, IKIP Budi Utomo, titikpurwati@budiutomomalang.ac.id

Fourth Author - Melisa Wahyu Fandyansari, S.Pd, M.Pd, lecturer, IKIP Budi Utomo,

melisawahyufandyansari@budiutomomalang.ac.id.

Correspondence Author - Melisa Wahyu Fandyansari, S.Pd, M.Pd, melisawahyufandyansari@ budiutomomalang.ac.id, melisawaf@gmail.com, +6281231192012. 